\title{
Agronomic performance of sugarcane cultivated under different amounts of sugarcane straw on the soil surface
}

\section{Desempenho agronômico da cana-de-açúcar cultivada sob diferentes quantidades de palhada da cultura na superfície do solo}

\author{
Mariana Alves de Oliveira ${ }^{1 *}$; Claudemir Zucareli; \\ Carmen Silvia Vieira Janeiro Neves²; Allan Ricardo Domingues ${ }^{3}$; \\ Cristiane de Conti Medina' ${ }^{2}$ Lucas Augusto de Assis Moraes ${ }^{3}$
}

\begin{abstract}
Mechanized harvesting has become increasingly common in the sugarcane production system. The sugarcane straw removed by mechanical harvesting could be converted into ethanol or be used to generate electricity by burning the material. At the same time, it is important to determine the amount of biomass that could be removed from the soil surface without damage to the cane crop. The agronomic performance of sugarcane was evaluated by growing the variety RB92579 under different amounts of sugarcane straw on the soil surface, in the first and second years of cane crop growth. An experimental randomized block in a split-plot design was used with four replications. In the first year the plots received five amounts of straw $\left(0.0,4.5,9.0,13.5\right.$, and $\left.18 \mathrm{Mg} \mathrm{ha}^{-1}\right)$, and six assessments $(60,120,180$, 240,300 , and 360 days after planting) were made in the subplots. In the second year, the plots received the same amount of straw and four assessments $(60,120,240$, and 540 days after the regrowth) in the subplots. Biometric indexes, components of production, and crop yield were evaluated. The data were submitted to variance analysis and polynomial regression $(\mathrm{p}<0.05)$. Increasing amounts of sugarcane straw deposited on the soil surface reduced the number and diameter of stalks at the beginning of crop establishment and the number of leaves for the first year. The maximum productivity of stalks was achieved by maintaining on the soil surface $9.6 \mathrm{Mg} \mathrm{ha}^{-1}$ of straw in the first year and $4.7 \mathrm{Mg} \mathrm{ha}^{-1}$ of straw in the second year of cane crop production.
\end{abstract}

Key words: Biomass. Green cane. Harvesting without burning. Saccharum spp.

\section{Resumo}

A colheita mecanizada está cada vez mais presente no sistema de produção de cana-de-açúcar. A palhada retirada durante a colheita pode ser convertida a etanol ou utilizada para geração de energia elétrica por meio da queima, sendo importante determinar a quantidade desta biomassa que pode ser removida, sem que haja prejuízos à cultura. Objetivou-se avaliar o desempenho agronômico da canade-açúcar, variedade RB92579, cultivada sob diferentes quantidades de palhada da cultura na superfície do solo, em cultivo de primeiro e segundo ciclo. Utilizou-se o delineamento experimental em blocos casualizados, com parcelas subdivididas no tempo, com quatro repetições. No primeiro ciclo as parcelas receberam cinco quantidades de palhada $\left(0,0 ; 4,5 ; 9,0 ; 13,5\right.$ e $\left.18 \mathrm{Mg} \mathrm{ha}^{-1}\right)$ e seis épocas de avaliação $(60,120,180,240,300,360$ dias após o plantio - DAP), dispostas nas subparcelas. No segundo ciclo,

${ }^{1} \mathrm{Dr}^{\mathrm{a}}$ em Agronomia, Universidade Estadual de Londrina, UEL, PR, Brasil. E-mail: agromariana.oliveira@gmail.com

2 Profs. Drs., Departamento de Agronomia, UEL, Londrina, PR, Brasil.E-mail: claudemircca@uel.br; csvjneve@uel.br; medina@ uel.br

${ }^{3}$ Discentes de Mestrado em Agronomia, UEL, Londrina, PR, Brasil. E-mail: allandomingez@hotmail.com; moraes1002@gmail. com

* Author for correspondence 
nas parcelas foram depositadas as mesmas quantidades de palhada e nas subparcelas foram dispostas as quatro épocas de avaliação (60, 120, 240 e 540 dias após a rebrota - DAR). Foram avaliadas as características fitométricas, os componentes de produção e a produtividade. Os dados foram submetidos à análise de variância e estudo de regressão polinomial $(\mathrm{p}<0,05)$. $\mathrm{O}$ aumento das quantidades de palhada depositadas na superfície do solo reduz o número e o diâmetro do colmo no início do estabelecimento da cultura, e o número de folhas para a cana de primeiro ciclo. A produtividade máxima de colmos é obtida com a manutenção de $9,6 \mathrm{Mg} \mathrm{ha}^{-1}$ de palhada para o primeiro ciclo e 4,7 $\mathrm{Mg} \mathrm{ha}^{-1}$ de palhada para o segundo ciclo.

Palavras-chave: Biomassa. Cana crua. Colheita sem queima. Saccharum spp.

\section{Introduction}

It is a common practice in the management of sugarcane crops to burn the sugarcane plantation prior to harvesting in order to eliminate the dense leaf biomass (straw) and to facilitate the manual cutting of the stalks. However, the burning releases pollutant gases, deposits ash in urban areas, and exposes the soil (LUCA et al., 2008). Given that sugarcane crop have expanded by occupying soils with low fertility, the burning of the plantation exacerbates this problem, particularly through the reduction of organic carbon (TAVARES et al., 2010).

Therefore, sugarcane production areas harvested without removing the straw through burning have become increasingly significant, particularly as producers are being spurred by legislation outlining progressive deadlines to increase the no-burn areas; 2017 has been established as the year to end the practice of plantation burning and to increase the efficiency of harvesting machines (TIMM et al., 2002).

In the raw cane harvesting system, the dry leaves, the tops, and the green leaves are cut and spread on the surface of the soil, forming a dense mulch. This material reduces erosion as it absorbs the kinetic energy from raindrops and reduces surface runoff; the straw efficiently reduces the loss of soil and water while increasing infiltration rates (BRAUNBECK; MAGALHÃES, 2010; VALIM et al., 2016). The straw also suppresses weeds (MONQUERO et al., 2008) and protects the soil against solar rays, which is beneficial to the microbiota and organic matter in the soil (LUCA et al., 2008; PANOSSO et al., 2011;
OLIVEIRA et al., 2014; PAREDES JUNIOR et al., 2015).

Values from 8 to $20 \mathrm{Mg} \mathrm{ha}^{-1}$ of dry straw material are typically found in plant-cane and ratoon production areas, depending on the variety, plantation age, and cultivation environment (CHRISTOFFOLETI et al., 2007). Souza et al. (2005) obtained $12 \mathrm{Mg} \mathrm{ha}^{-1} \mathrm{yr}^{-1}$ of straw in a raw cane system in a dystrophic red-yellow latosol, and this system with a partial incorporation of crop residue improved the physical conditions of the soil and increased the production potential of the crop.

On the other hand, laying and maintaining straw on the surface of the soil may cause problems in managing the crop, such as difficulties in controlling weeds and an increase in the population of pests beneath the straw (MACEDO et al., 2003). The volume of straw covering the ratoon cane may hamper its emergence, undermining regrowth, especially in improved varieties that were developed for the harvest system with burning (VASCONCELOS, 2002).

The straw is also an inexpensive raw material that is readily available as a source of renewable lignocellulosic biomass, which can be converted to ethanol (DAWSON; BOOPATHY, 2007) or used to generate electrical energy through burning. Thus, studies are needed on the optimal amount of straw to be maintained on the soil surface, which will favor the sustainability of the production system and the development and productivity of the sugarcane, without compromising regrowth or hampering the possibility of using excess straw to produce energy. 
Therefore, this study aimed to evaluate the agronomic performance of sugarcane, variety RB92579, grown under different amounts of sugarcane straw on the surface of the soil, in firstand second-cycle crops.

\section{Material and Methods}

The experiment was conducted in field conditions at the Bandeirantes Sugar and Alcohol Plant (Usina de Açúcar e Álcool Bandeirantes (USIBAN)), in the city of Bandeirantes, PR, at $23^{\circ} 06^{\prime} \mathrm{S}, 50^{\circ} 21^{\prime}$ $\mathrm{W}$, and an altitude of $440 \mathrm{~m}$. The climate in the region according to the Köppen classification is mesothermal humid subtropical (CFA), with hot summers and infrequent frosts (IAPAR, 2015). The meteorological data from the period when the experiment was conducted were obtained from the meteorological station of the Agronomic Institute of Paraná (Figure 1).

Figure 1. Daily maximum and minimum temperatures and rainfall data for the first (A) sugarcane crop cycle, from September 2012 to October 2013, and the second (B) sugarcane crop cycle, from October 2013 to April 2015, conducted in Bandeirantes, PR.
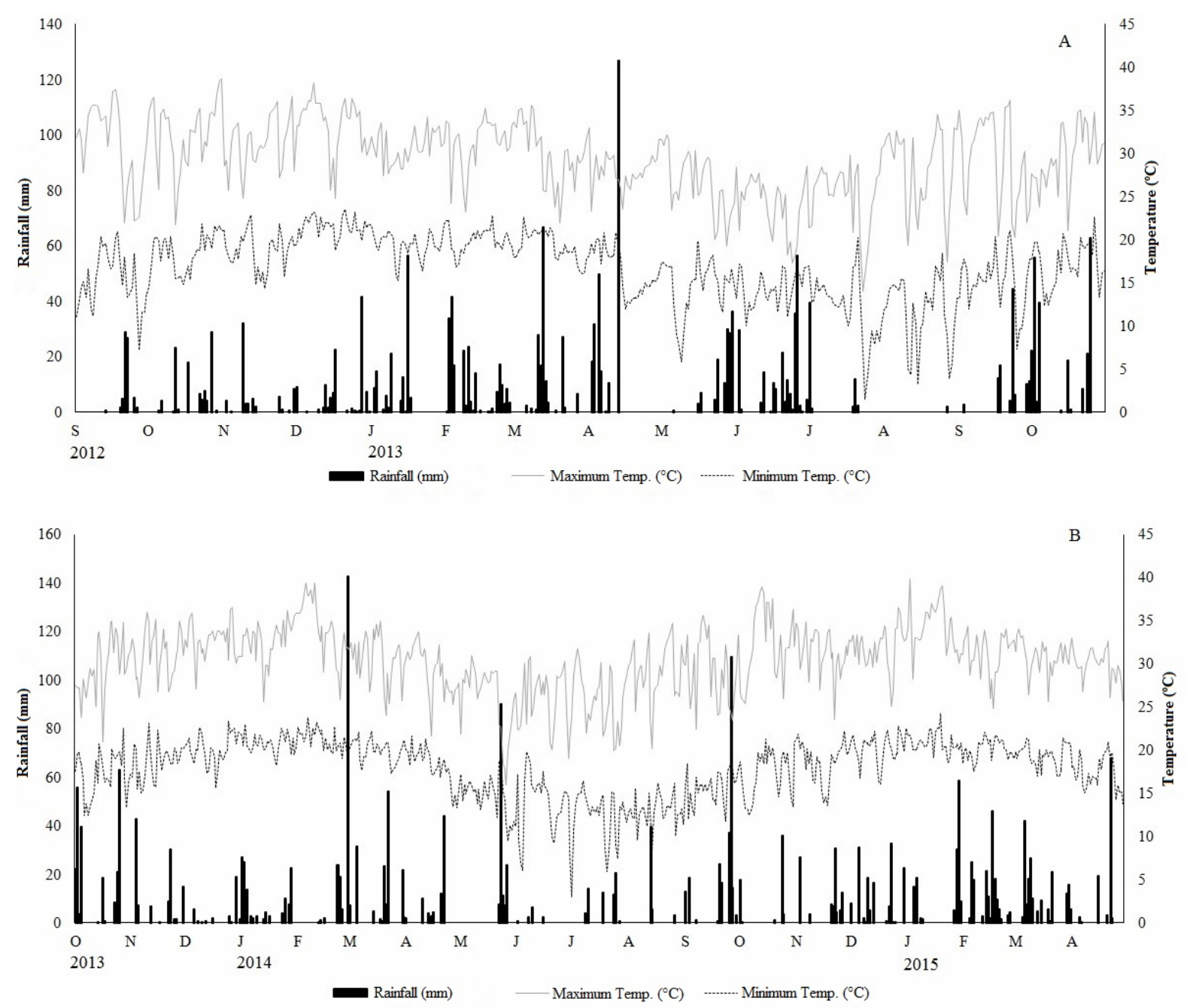
The experiment was installed in a dystrophic red latosol with a clayey texture (EMBRAPA, 2006). Prior to the installation of the experiment, soil samples from the area were collected at depths of 0-20 cm for chemical analysis (RAIJ; QUAGGIO, 1983), exhibiting a $\mathrm{pH} \mathrm{CaCl}_{2}$ of 4.4 ; OM of $8.68 \mathrm{~g}$ $\mathrm{kg}^{-1}$; P of $3.56 \mathrm{mg} \mathrm{dm}^{-3}$; $\mathrm{Al}$ of $0.13 \mathrm{cmol}_{\mathrm{c}} \mathrm{dm}^{-3} ; \mathrm{H}+\mathrm{Al}$ of $4.84 \mathrm{cmol}_{\mathrm{c}} \mathrm{dm}^{-3} ; \mathrm{K}^{+}$of $0.07 \mathrm{cmmol}_{\mathrm{c}} \mathrm{dm}^{-3} ; \mathrm{Ca}^{2+}$ of $3.57 \mathrm{cmmol}_{\mathrm{c}} \mathrm{dm}^{-3} ; \mathrm{Mg}^{2+}$ of $0.50 \mathrm{cmmol}_{\mathrm{c}} \mathrm{dm}^{-3}$; SB of $4.14 \mathrm{cmmol}_{\mathrm{c}} \mathrm{dm}^{-3}$; CEC of $4.27 \mathrm{cmmol}_{\mathrm{c}} \mathrm{dm}^{-3}$; $\mathrm{CEC}_{\mathrm{pH} 7,0}$ of $8.98 \mathrm{cmmol}_{\mathrm{c}} \mathrm{dm}^{-3}$; and $\mathrm{V} \%$ of 46.10 . Approximately two months before planting, $350 \mathrm{~kg}$ $\mathrm{ha}^{-1}$ of Gafsa phosphate was applied, homogenously distributed in the area, and incorporated with a leveling disc harrow. For the maintenance fertilization, $640 \mathrm{~kg} \mathrm{ha}^{-1}$ of the 05-30-15 (N-P-K) formula was applied, distributed at the bottom of the furrows shortly before planting.

The study was conducted over two crop cycles. The first crop of plant-cane was established on September 20, 2012, with a cycle duration of 12 months. It was planted manually in an area prepared through heavy and light harrowing, in furrows with a depth of $0.15 \mathrm{~m}$, with 14 shoots per linear meter of the variety RB92579, which exhibits excellent productivity, good closure between furrows, and excellent sprouting of ratoons (RIDESA, 2010). Each plot consisted of 10 furrows with a length of $10 \mathrm{~m}$ and spaced $1.5 \mathrm{~m}$ apart. The usable area consisted of six central rows, disregarding $0.50 \mathrm{~m}$ in the extremities.

Thirty treatments were performed in the first cycle, using an experimental design of randomized blocks in split plots in time, with four replications. The main plots received five amounts of sugarcane straw, 0.0, 4.5, 9.0, 13.5, and $18 \mathrm{Mg} \mathrm{ha}^{-1}$, and the subplots consisted of six evaluation times, 60, 120, 180, 240, 300, and 360 days after planting (DAP). The straw was obtained from a commercial sugarcane plantation of variety RB92579, originating from mechanized harvesting. The maximum amount of straw produced by this variety was estimated by weighing the dry mass of straw contained in an area the size of the plot and estimated for $\mathrm{Mg} \mathrm{ha}^{-1}$. It was laid out manually, with uniform distribution of the straw on the plot.

After the first cycle was harvested, the treatments of laying straw on the surface of the soil were reestablished for the second cycle (ratoon cane), over the course of 18 months, following the same experimental design, with the same amount of straw laid out on the main plots and four evaluation times for the sub-plots, 60, 120, 240, and 540 days after regrowth (DAR), with four replications. During crop development, the experimental area was monitored for pests and weeds, which were controlled according to recommendations for the crop.

Each evaluation was performed at $2 \mathrm{~m}$ on the planting row, in the usable area of each plot. Ten random plants were taken for an evaluation of the following phytometric characteristics: stalk length, which was obtained with a graduated ruler, from the base of the plant to leaf $+1(\mathrm{~m})$; number of leaves per tiller, considering the fully expanded and photosynthetically active leaves (minimum 20\% green area), from leaf +1 ; and leaf area of leaf +1 , which entailed the collection of the highest leaf with a perfectly visible auricle, in accordance with the Kuijper system (CASAGRANDE, 1991). A Li-Cor leaf area meter (model LI-3100) was used, and the output was expressed in $\mathrm{cm}^{2}$ according to the number of stalks from the sampled area. To determine the mass of the dry material of leaf +1 , after obtaining the leaf area, the leaves were packed in paper bags and dried in an oven with forced air circulation at $65^{\circ} \mathrm{C}$ until a constant mass was obtained; the output was expressed in $\mathrm{g}$ according to the number of stalks.

The production components were calculated as follows: the number of stalks was defined by counting the tillers within the $2 \mathrm{~m}$ evaluation area; the stalk diameter was obtained in the median region of the first internode above the soil, from 10 plants taken randomly, with the help of a manual 
caliper $(\mathrm{cm})$; to determine the dry mass of stalks, the stalks were subdivided and sampled, comprising three sub-samples of known mass, which were dried in an oven with a forced air circulation at $80^{\circ} \mathrm{C}$ until a constant mass was obtained. The dry mass of the stalks was obtained by the mean of the sub-samples of the dry mass in relation to the mean of the sub-samples of the green mass of the stalks initially weighed, according to the total green mass of the stalks, with results in $\mathrm{kg}$. To determine stalk productivity, at 360 DAP (first cycle) and 540 DAR (second cycle), the stalks were collected from the usable area of the plot to obtain the stalk mass per plot, with a calculation for $\mathrm{Mg} \mathrm{ha}^{-1}$.

The homoscedasticity (Bartlett's test) and error normality (Lilliefors test) of the data were tested and subsequently submitted to analysis of variance and polynomial regression $(p<0.05)$, in which the statistics program Sisvar was used (FERREIRA, 2010).

\section{Results and Discussion}

In cultivating the first cycle, a significant alteration in stalk length, leaf area, and mass of dry material of leaf +1 was found according to the evaluation times, and in the number of leaves per tiller according to the amount of straw laid on the soil surface (Table 1). The interaction between the factors - the amount of straw and evaluation times - was significant for the number of stalks. For 0 and $4.5 \mathrm{Mg} \mathrm{ha}^{-1}$ of straw, there was a quadratic adjustment according to the evaluation time for the number of stalks (Figure 2A). The number of stalks was not influenced by the laying of straw from 9.0 $\mathrm{Mg} \mathrm{ha}^{-1}$ and above according to evaluation time.

Table 1. Analysis of variance (mean squares) of the number of stalks (NS), stalk length (SL), number of leaves per tiller (NLT), leaf area of leaf +1 (LA), and mass of the dry material of leaf +1 (MDML), according to the amount of straw and evaluation time of the first-cycle sugarcane. Bandeirantes, PR, 2012/2013.

\begin{tabular}{ccccccc}
\hline \multirow{2}{*}{$\begin{array}{l}\text { Variation } \\
\text { Source }\end{array}$} & DF & \multicolumn{5}{c}{ Analyzed Variables } \\
\cline { 3 - 6 } & & NS & SL $(\mathbf{c m})$ & NLT & LA $\left(\mathbf{c m}^{2}\right)$ & MDML $\left(\mathbf{c m}^{2}\right)$ \\
\hline Block & 3 & 14.1638 & 0.0425 & 2.9383 & 25916.10 & 2.9533 \\
Straw & 4 & $76.3875 \mathrm{~ns}$ & $0.1025 \mathrm{~ns}$ & $3.4697 *$ & $5216.26 \mathrm{~ns}$ & $0.8841 \mathrm{~ns}$ \\
Error 1 & 12 & 62.7541 & 0.0397 & 0.9115 & 5756.10 & 0.9343 \\
Time & 5 & $583.7350 *$ & $28.3806 *$ & $49.3142 *$ & $236646.64 *$ & $54.1437 *$ \\
Time x Straw & 20 & $102.3225 *$ & $0.0227 \mathrm{~ns}$ & $0.2324 \mathrm{~ns}$ & $3543.46 \mathrm{~ns}$ & $0.8793 \mathrm{~ns}$ \\
Error 2 & 75 & 3511.7083 & 0.0285 & 0.8224 & 5725.58 & 0.9306 \\
\hline CV 1 (\%) & & 29.87 & 8.77 & 21.87 & 34.15 & 20.70 \\
CV 2 (\%) & & 25.80 & 7.43 & 20.78 & 34.06 & 20.66 \\
Mean & & 26.52 & 2.27 & 4.36 & 222.15 & 4.67 \\
\hline
\end{tabular}

NOTE: $\mathrm{ns}=$ not significant by the $\mathrm{F}$ test; $*=$ significant by the $\mathrm{F}$ test $(p<0.05)$. DF: degrees of freedom.

The treatment without added straw showed a minimum point at $286 \mathrm{DAP}$ and the laying of $4.5 \mathrm{Mg}$ $\mathrm{ha}^{-1}$ of straw showed a minimum point at 244 DAP. Thus, the presence of $4.5 \mathrm{Mg} \mathrm{ha}^{-1}$ of straw led to the mean emission of tillers 42 days prior than in the absence of straw. Tavares et al. (2010) found greater tillering in a raw cane system with the presence of straw, as compared to the burnt cane system. Maintaining straw on the surface of the soil provides a favorable microclimate for the crop, characterized by a greater water content (VASCONCELOS, 2002) and higher concentrations of organic matter 
in the soil (MENDONZA et al., 2000), as well as a lower thermal range (OLIVEIRA et al., 2001) and greater soil surface protection against the impact of raindrops, all of which is beneficial to the decomposition of organic residue and the availability of nutrients (CEDDIA et al., 1999; FREITAS et al.,
2004). The practice also hampers weed survival, as it acts as a physical barrier and impedes light penetration (PITELI; DURIGAN, 2001). The straw can release allelopathic substances, enabling greater control of invasive plants (AZANIA et al., 2006).

Figure 2. Means for the number of sugarcane stalks, variety RB92579, according to evaluation time (A) and amount of straw (B), in the first-cycle crop.

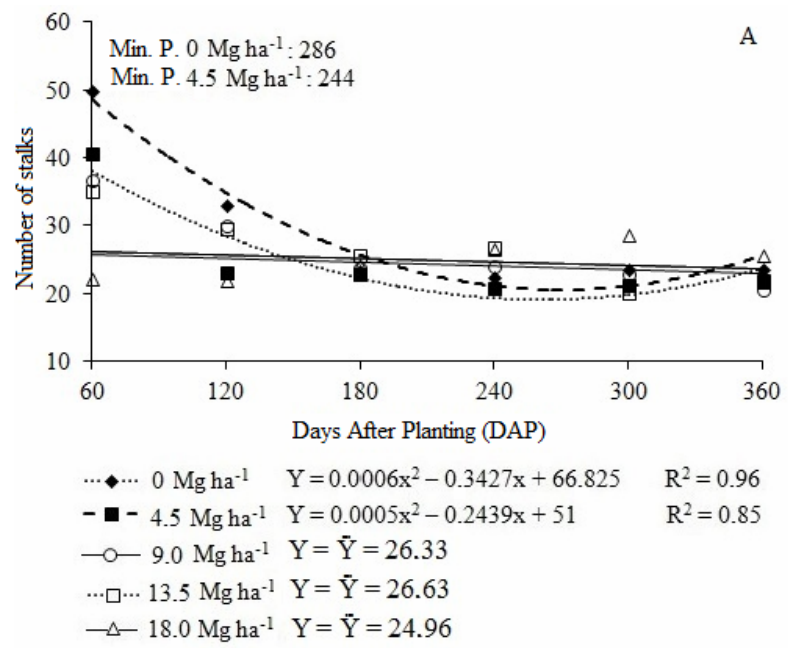

At 60 DAP there was a linear reduction in the number of stalks with an increase in the amount of straw on the soil surface (Figure 2B). According to Vasconcelos (2002), the sprouting and the beginning of tillering tend to be slower under the layer of straw, as compared to the absence of straw. Thus, the residue acts as a mechanical barrier and, mainly, as a reducer of light penetration for the first sprouted tillers, reducing initial photosynthesis. There are also signs that the allelochemical compounds released by the straw, in addition to their effects on weeds (RICE, 1984), may cause phytotoxicity in the crop (VELINI; NEGRISOLI, 2001), hampering its establishment. After $120 \mathrm{~d}$, no influence was seen from the amount of straw on the number of stalks, demonstrating that the crop recovered the capacity to emit tillers, regardless of the amount of straw deposited, without losses throughout the cycle (Figure 2B). Most sugarcane varieties show greater

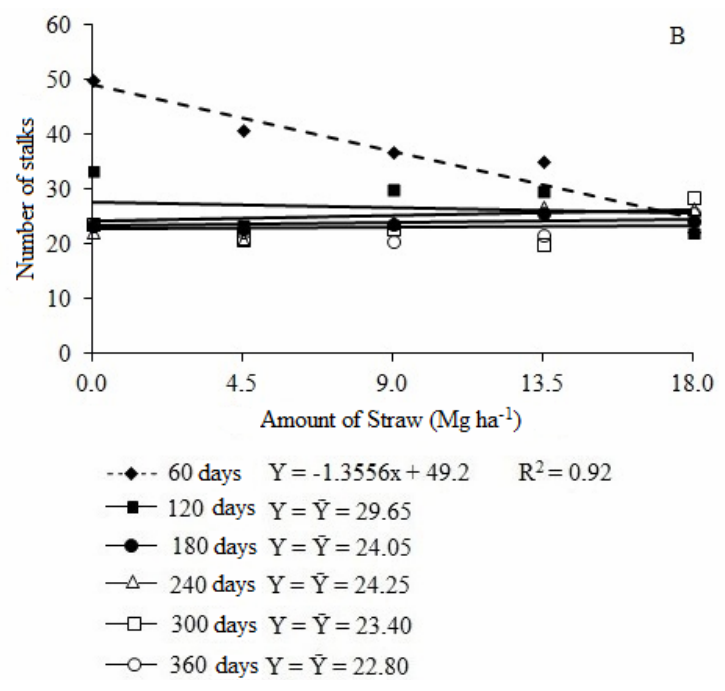

tillering under straw in early development, but after a few months is equivalent to those varieties grown free of straw (VASCONCELOS, 2002), as observed in this study.

Stalk length was not influenced by the spreading of straw on the soil (Figure 3A) and showed a linear adjustment according to evaluation time (Figure 3B). Plant development benefited from the adequate conditions of maximum temperatures and water availability during the crop cycle (Figure 1A), favoring stalk growth.

The increase in the amount of straw deposited reduced the number of leaves per tiller (Figure 3C), with a delay in tillering and consequently in plant development. The number of leaves according to evaluation time showed a quadratic adjustment, with the maximum point of efficiency at 166 DAP (Figure 3D), and with a subsequent decline until 
harvest. Ramesh (2000) reports that once the phase of intense growth is over, the crop reduces the expenditure of energy in the production of leaves and senescence occurs, and the competition for light by the tillers results in the loss of leaves.

The leaf area of leaf +1 and the mass of the dry material of leaf +1 were not influenced by the laying of straw, with an average of $222.15 \mathrm{~cm}^{2}$ and $4.67 \mathrm{~g}$
(Figures 4A and 4C), respectively. However, there was an effect from evaluation time, with a quadratic adjustment; maximum leaf area of leaf +1 occurred at 220 DAP (Figure 4B) and maximum mass of dry material occurred at 312 DAP (Figure 4D). Aquino and Medina (2012) obtained a maximum response for IAF at 180 DAP in a system under straw, which then showed a subsequent decline.

Figure 3. Stalk length and number of leaves per tiller, according to the amount of straw (A and C) and evaluation time (B and D), in the first-cycle crop of sugarcane, variety RB92579.
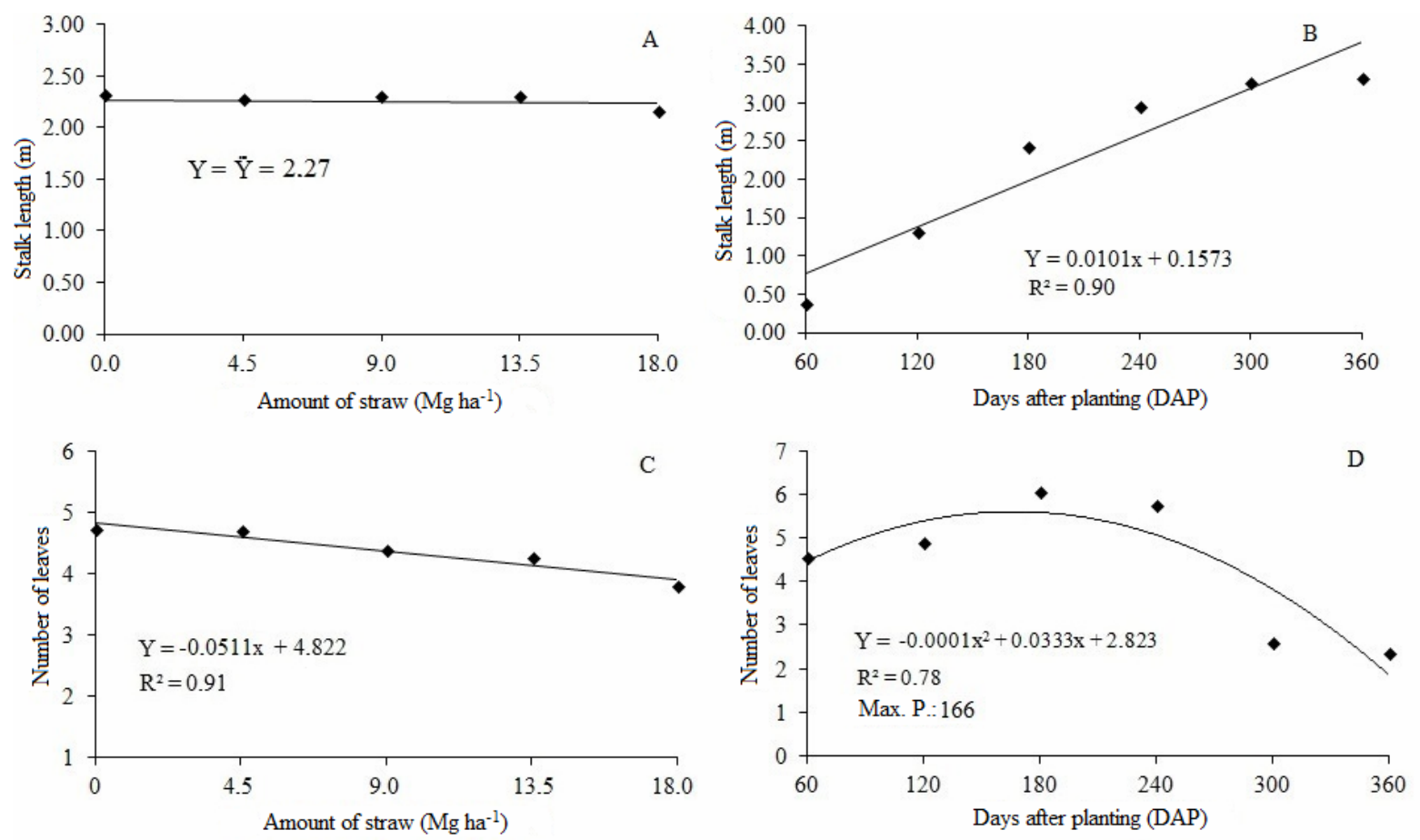

The dry mass of stalks was affected by the evaluation time and the productivity of the stalks was affected by the amount of straw, with a significant interaction between the factors only for stalk diameter (Table 2). For stalk diameter, in the treatment without straw, there was a linear adjustment according to evaluation time, with a progressive increase during crop development (Figure 5A). For the other amounts evaluated (4.5 to $18.0 \mathrm{Mg} \mathrm{ha}^{-1}$ of straw), there was a quadratic adjustment according to evaluation time. The presence of $13.5 \mathrm{Mg} \mathrm{ha}^{-1}$ of straw exhibited a maximum efficiency at 222 DAP, demonstrating the positive effect of the added straw

preceding the maximum increase in stalk diameter in relation to the other treatments. A diverging result was observed by Aquino and Medina (2012), who did not obtain an effect with the treatments (burning; 0.0, 5.5, 11.0, 16.5, and $22 \mathrm{Mg} \mathrm{ha}^{-1}$ of straw) on stalk diameter, in the periods of 60,180 , 270, and 350 DAP. At 60 DAP there was a linear reduction in stalk diameter with the increase in the amount of straw (Figure 5B). At 120 DAP there was a quadratic adjustment according to the amount of straw, with a maximum stalk diameter at $9.3 \mathrm{Mg} \mathrm{ha}^{-1}$ of added straw. 
Figure 4. Leaf area and mass of dry material of leaf +1 , according to amount of straw (A and C) and evaluation time (B and D), in the first-cycle crop of sugarcane, variety RB92579.
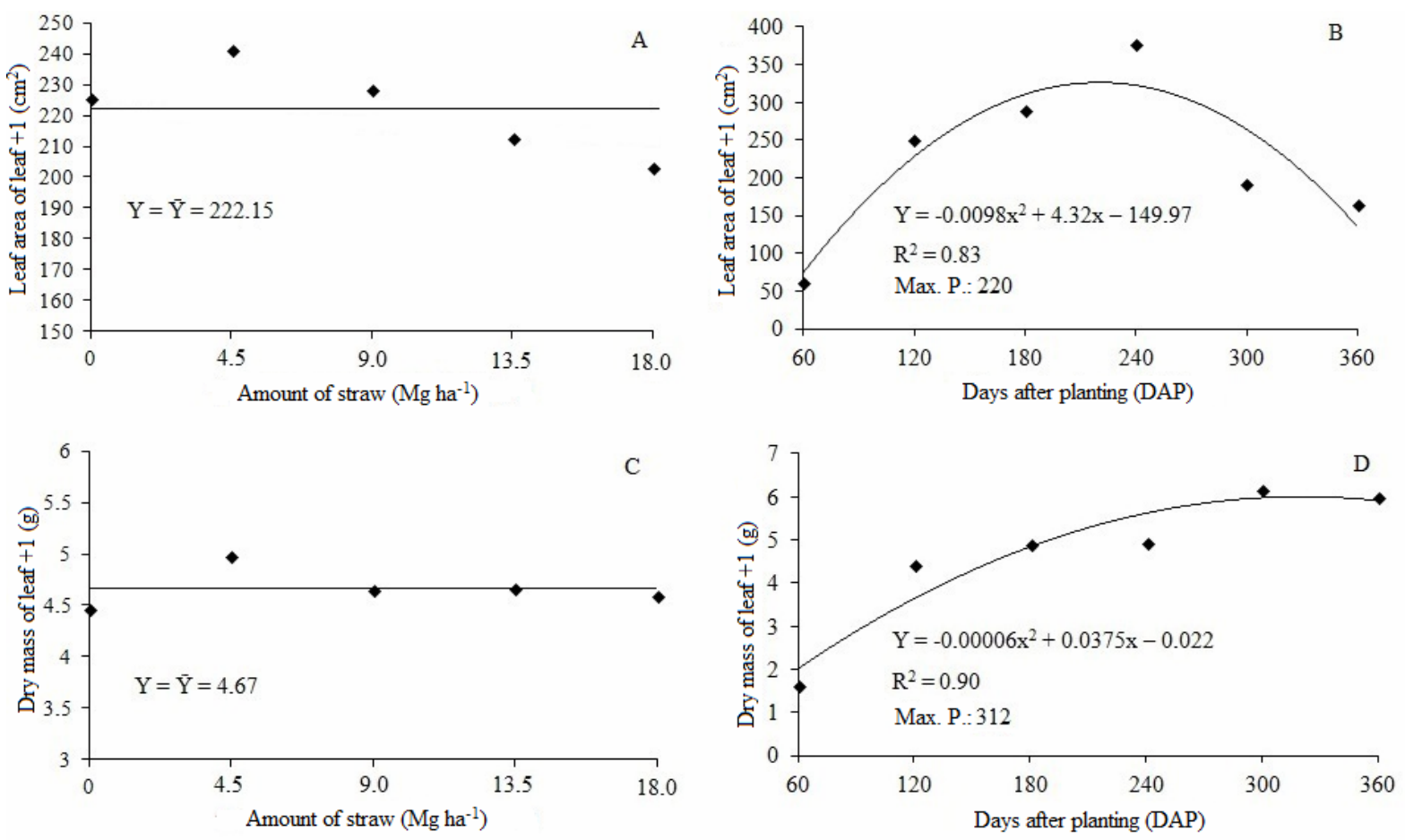

Table 2. Analysis of variance (mean squares) of the stalk diameter (SD), dry mass of stalk (DMS), and stalk productivity (P) according to the amount of straw and evaluation time for first-cycle sugarcane. Bandeirantes, PR, 2012/2013.

\begin{tabular}{ccccc}
\hline Variation Source & DF & SD $(\mathbf{c m})$ & $\begin{array}{c}\text { Variables Analyzed } \\
\text { DMS (kg) }\end{array}$ & P (kg ha $\left.\mathbf{~}^{-\mathbf{1}}\right)$ \\
\hline Block & 3 & 0.0244 & 3622405.89 & 182.7731 \\
\hline Straw & 4 & $0.06167 \mathrm{~ns}$ & $4183298.25 \mathrm{~ns}$ & $316.0719^{*}$ \\
Error 1 & 12 & 0.0353 & 4430787.02 & - \\
Time & 5 & $2.4419^{*}$ & $644711118.76 *$ & - \\
Time x Straw & 20 & $0.0730^{*}$ & $4042837.78 \mathrm{~ns}$ & - \\
Error 2 & 75 & 0.0369 & 3932124.00 & 85.2815 \\
\hline CV 1 (\%) & & 6.52 & 33.94 & - \\
CV 2 (\%) & 6.66 & 31.97 & 8.87 \\
Mean & & 2.88 & 6202.54 & 84.96 \\
\hline
\end{tabular}

NOTE: $\mathrm{ns}=$ not significant by the $\mathrm{F}$ test; $*=$ significant by the $\mathrm{F}$ test $(p<0.05)$. DF: degrees of freedom

The dry mass of stalks was not influenced by the amount of added straw, with an average of $6.20 \mathrm{~kg}$ (Figure 6A). The results for the dry mass of stalks is in agreement with those observed by Gava et al. (2001). The authors found that the accumulation of dry mass in the aerial part in the different growth stages and in the harvesting of ratoon cane, variety
SP 801842, did not change with the laying of straw on the soil surface. The dry mass of the stalks showed an increasing linear adjustment in response to the evaluation times (Figure 6B). From 120 DAP on, there was an increasing accumulation of dry mass of the stalks coinciding with adequate climate conditions from January to May (Figure 1A), which 
favored plant development of the crop. These results corroborate those of Oliveira et al. (2007), who point out the greater growth of the aerial part of the sugarcane from January to March, due to adequate temperature and rainfall conditions.

Figure 5. Means for stalk diameter, according to evaluation time (A) and amount of straw (B), in the first-cycle crop of sugarcane, variety RB92579.
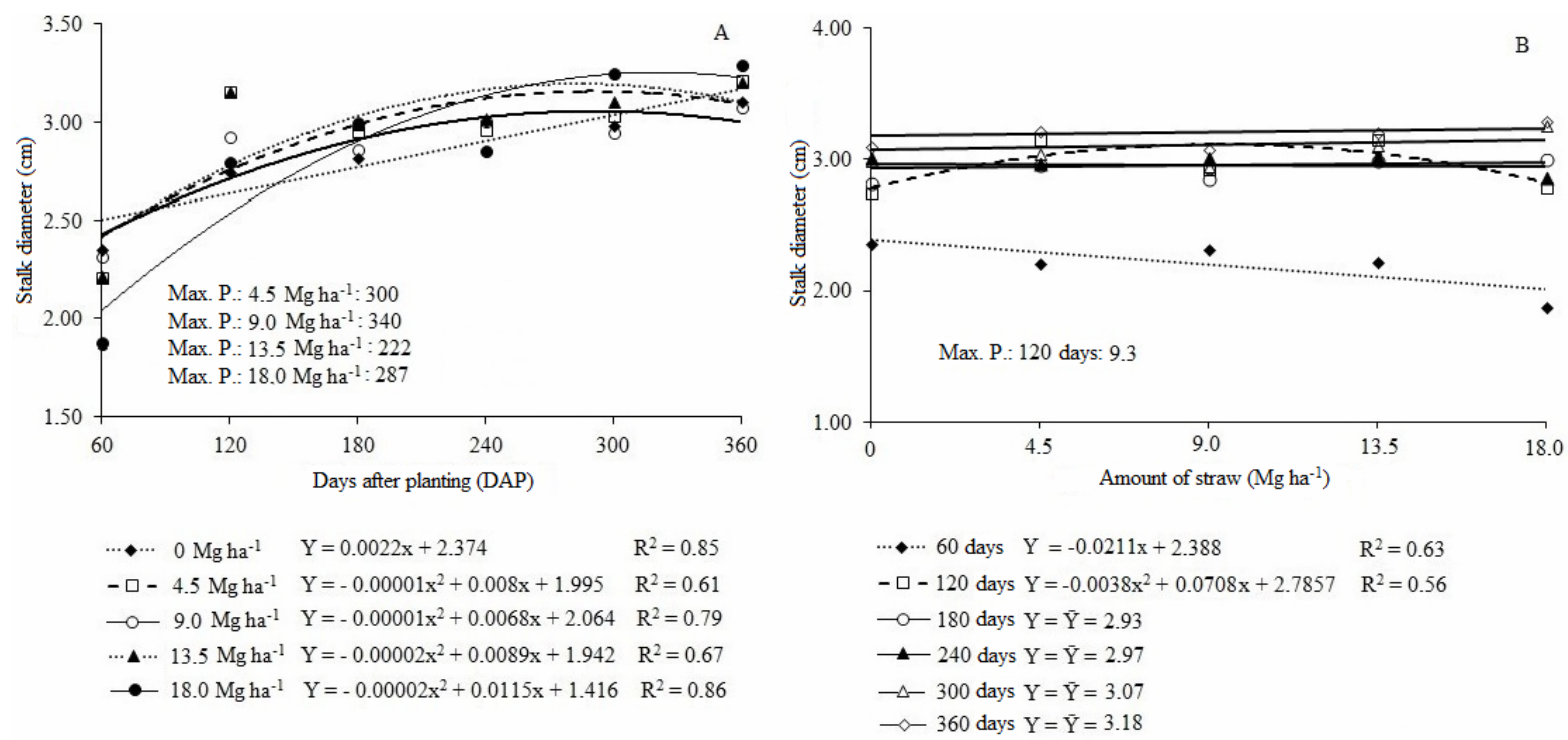

Figure 6. Dry mass and stalk productivity, according to amount of straw (A and C) and evaluation time (B), in the first-cycle crop of sugarcane, variety RB92579.
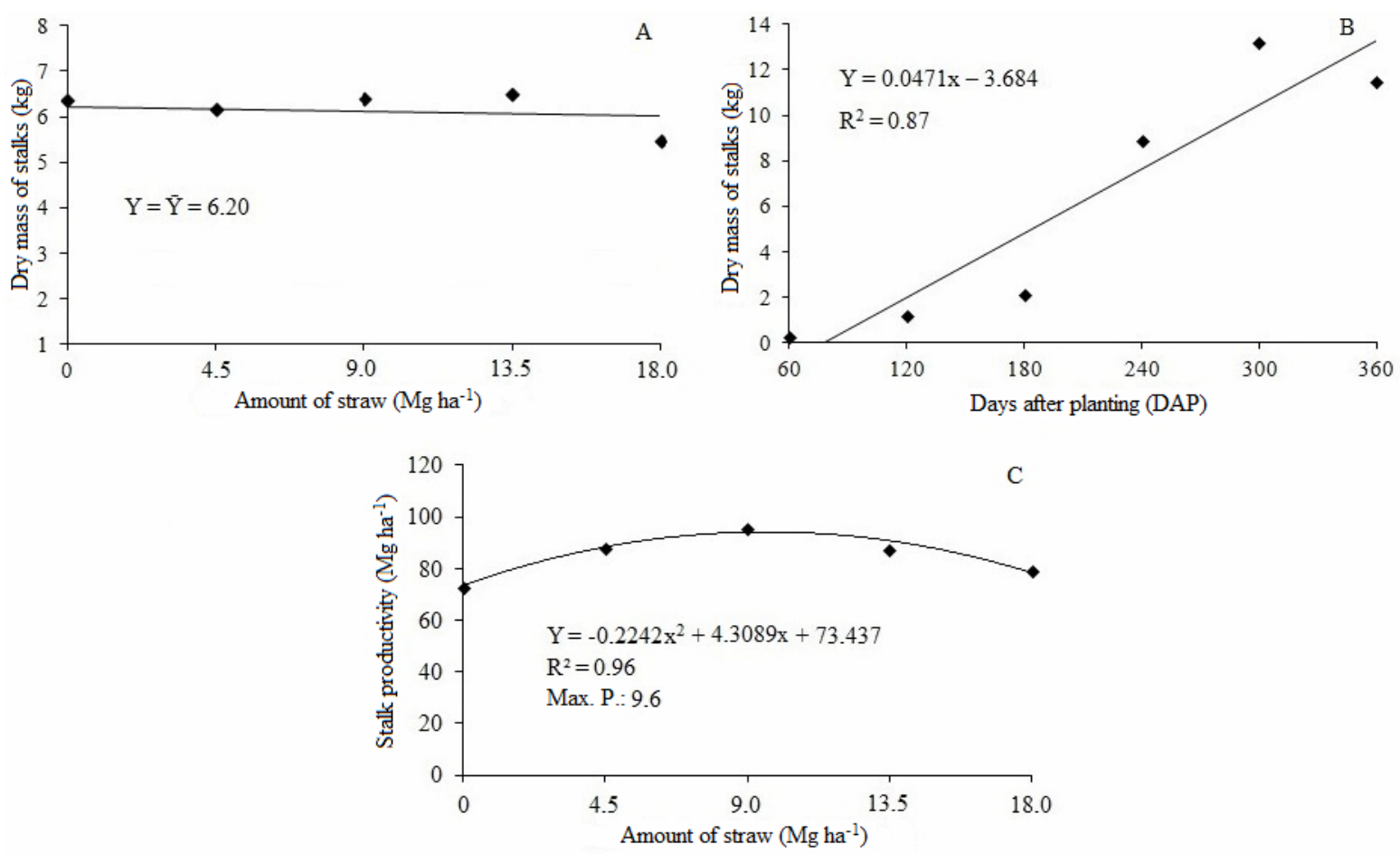
Stalk productivity at 360 DAP exhibited a quadratic adjustment according to the amount of straw, obtaining a maximum point with $9.6 \mathrm{Mg}$ $\mathrm{ha}^{-1}$, which corresponds to $94.14 \mathrm{Mg} \mathrm{ha}^{-1}$ of stalks (Figure 6C). Tavares et al. (2010) found that the treatments with burning and without burning the residue did not result in a significant difference between the productivities of stalks in plant-cane, achieving a mean productivity of $92.33 \mathrm{Mg} \mathrm{ha}^{-1}$. In a raw cane system, Souza et al. (2005) reported that the addition of $12 \mathrm{Mg} \mathrm{ha}^{-1}$ of straw produced 134.19 $\mathrm{Mg} \mathrm{ha}{ }^{-1}$ of stalks.
In the second crop cycle, a significant change in the number, length, and diameter of the stalks and in the number of leaves per tiller was found according to evaluation time. There was no significant effect from laying straw on the soil and the interaction between the factors studied (Table 3). As for stalk productivity, evaluated at 540 DAR, a significant effect was found on the amount of straw laid on the soil surface. The straw on the soil surface did not influence second-cycle cane regrowth. The same was found by Tavares et al. (2010), disproving a negative influence of straw on sprouting.

Table 3. Analysis of variance (mean squares) of the number of stalks (NS), stalk length (SL), stalk diameter (SD), number of leaves per tiller (NLT), and stalk productivity (P), according to the amount of straw and evaluation time of second-cycle sugarcane. Bandeirantes, PR, 2013/2015.

\begin{tabular}{ccccccc}
\hline Variation & \multirow{2}{*}{ DF } & \multicolumn{5}{c}{ Analyzed Variables } \\
\cline { 3 - 6 } Source & & NS & SL $(\mathbf{c m})$ & SD $(\mathbf{c m})$ & NLT & P $\left(\mathbf{M g ~ h a}^{-1}\right)$ \\
Block & 3 & 110.9500 & 0.3038 & 0.0843 & 0.1671 & 311.450 \\
Straw & 4 & $36.2312 \mathrm{~ns}$ & $0.1103 \mathrm{~ns}$ & $0.1224 \mathrm{~ns}$ & $0.6689 \mathrm{~ns}$ & $389.6415^{*}$ \\
Error 1 & 12 & 50.1479 & 0.0936 & 0.0866 & 0.5978 & - \\
Time & 3 & $505.9500 *$ & $3.3037 *$ & $5.7802 *$ & $106.7921 *$ & - \\
Time x Straw & 12 & $68.9395 \mathrm{~ns}$ & $0.0258 \mathrm{~ns}$ & $0.0947 \mathrm{~ns}$ & $0.1695 \mathrm{~ns}$ & - \\
Error 2 & 45 & 48.6416 & 0.0589 & 0.0652 & 0.6423 & 202.057 \\
\hline CV 1 (\%) & & 22.61 & 19.47 & 12.95 & 13.82 & - \\
CV 2 (\%) & & 22.26 & 15.45 & 11.24 & 14.32 & 5.06 \\
Average & & 31.32 & 1.57 & 2.27 & 5.6 & 88.82 \\
\hline
\end{tabular}

NOTE: $\mathrm{ns}=$ not significant by the $\mathrm{F}$ test; $*=$ significant by the $\mathrm{F}$ test $(p<0.05)$. DF: degrees of freedom.

The number of stalks averaged 16 stalks per linear meter, with an average length of $1.57 \mathrm{~m}$ (Figures 7A and 7C) and an average diameter of $2.27 \mathrm{~cm}$ (Figure 7E). Similar results for the number of stalks were found by Alvarez and Castro (1999), where the tillering was similar for the production systems, raw cane and burnt cane, in the first year of ratoon cane, with an average of 21 tillers per meter for raw cane and 20 for burnt cane.

The variables of stalk diameter, length, and number showed a quadratic adjustment according to evaluation time, with a minimum for the number of stalks at 276 DAR (Figure 7B), maximum stalk length at 365 DAR (Figure 7D), and maximum diameter at 480 DAR (Figure 7F). There was a reduction in tillering in the intermediate phase of crop development, with the stabilization of resprouting at the end of the cycle (Figure 7B). This behavior is due to the reduction in rainfall in May, July, and August, accompanied by the incidence of low temperatures, with greater water availability resuming from September on (Figure 1B). Aquino and Medina (2012) identified a positive effect of keeping straw on the soil surface, with increases in the number of stalks at 180 and 350 DAP, for caneplant cultivation of variety SP $80-1816$, on very clayey soil.

Stalk diameter over the course of plant development showed a reduction in relation to the 
start of development Alvarez and Castro (1999) at 60 DAP. also found a reduction in stalk diameter in cane harvested raw in the first and second years. The authors argued that this reduction might be related to self-shading, which results in thinner stalks.
The number of leafs per tiller showed an average of 5.6 without a significant effect from the amount of straw (Figure 8A). However, there was a quadratic adjustment according to evaluation time, showing a maximum point at 362 DAR (Figure $8 \mathrm{~B}$ ), a similar behavior as that observed in the first cycle.

Figure 7. Stalk number, length, and diameter, according to the amount of straw (A, C, and E) and evaluation time (B, $\mathrm{D}$, and F), in the second-cycle crop of sugarcane, variety RB92529.
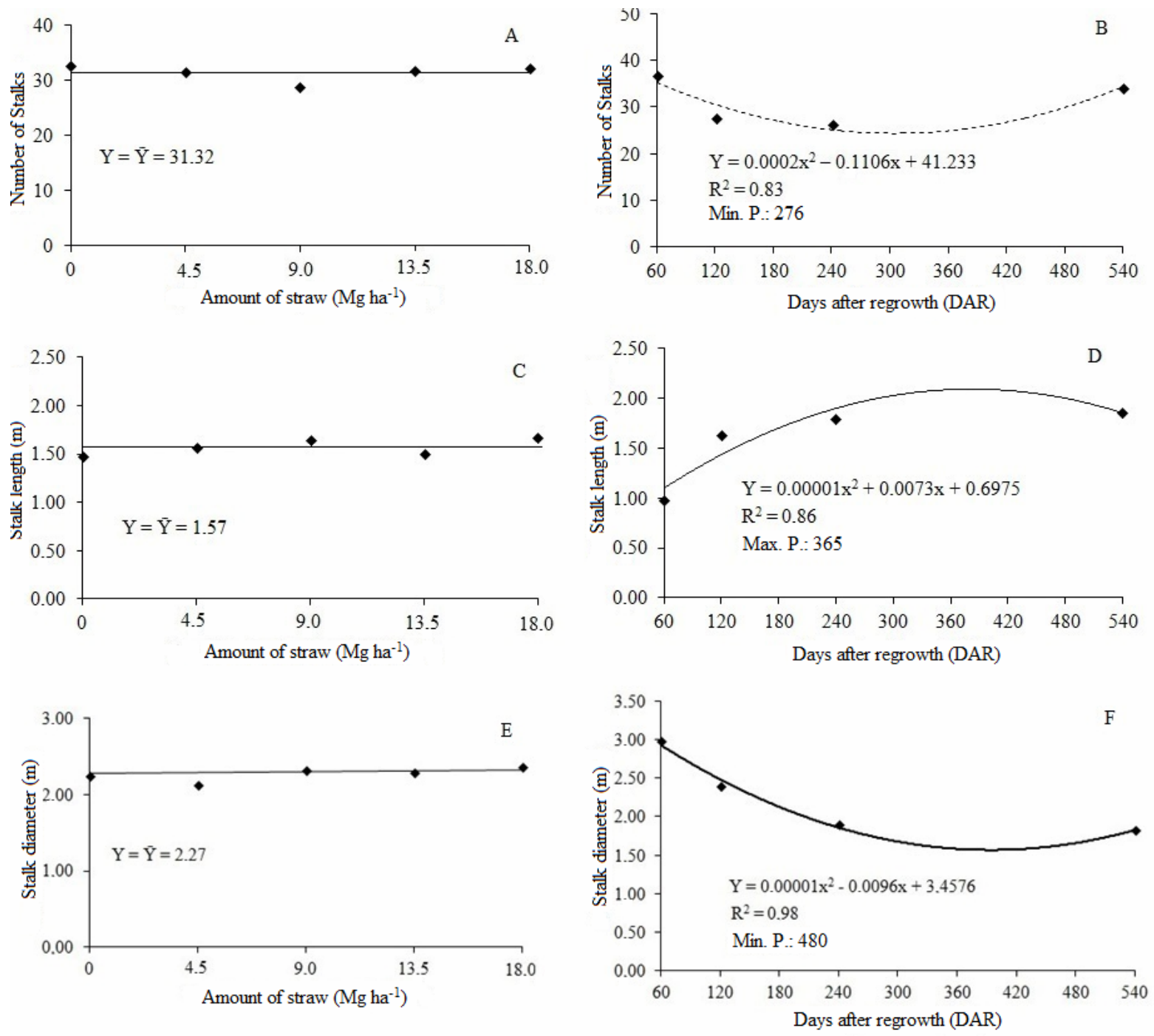

Stalk productivity at 540 DAR showed a quadratic adjustment according to the amount of straw, with a maximum point at $4.7 \mathrm{Mg} \mathrm{ha}^{-1}$ (Figure 8C). Maintaining $4.7 \mathrm{Mg} \mathrm{ha}^{-1}$ of straw resulted in productivity of $96.3 \mathrm{Mg} \mathrm{ha}^{1}$ of stalks. The second cycle showed satisfactory performance, with the

maintenance of half the straw required by the first cycle - around $9.6 \mathrm{Mg} \mathrm{ha}^{-1}$ of straw for the first and 4.7 $\mathrm{Mg} \mathrm{ha}^{-1}$ for the second crop cycles. Stalk productivity for the first cut was $94.03 \mathrm{Mg} \mathrm{ha}^{-1}$, which was below the Brazilian average of $98.8 \mathrm{Mg} \mathrm{ha}^{-1}$ for the first cut, which occurred in the 2013/2014 crop 
(CONAB, 2015). This lower result than the national average may be attributed to the dry spell associated with low temperatures in July and August (Figure 1A). The maximum productivity for the second cut was $96.3 \mathrm{Mg} \mathrm{ha}^{-1}$, which was greater than the average of the 2014/2015 crop for the second cut of $80 \mathrm{Mg} \mathrm{ha}^{-1}$ (CONAB, 2015). For the cane harvest system of variety RB 739735 with no burning and a subsequent distribution of $16.7 \mathrm{Mg} \mathrm{ha}^{-1}$ of residue on the soil, Ceddia et al. (1999) found an average stalk productivity in the first and second cycles of 138.0 $\mathrm{Mg} \mathrm{ha}^{-1}$ and $91.2 \mathrm{Mg} \mathrm{ha}^{-1}$, respectively, which was higher than that found in this study. Gava et al. (2001) point out that the variations found in the literature for sugarcane productivity, according to the presence of soil covered with straw, are possibly related to the time of implementation of the no-burn system, the heat and water conditions of each region, the soil compaction, and the sugarcane variety.

Figure 8. Number of leaves and stalk productivity, according to amount of straw (A and C) and evaluation time (B), in the second-cycle sugarcane crop, variety RB92579.
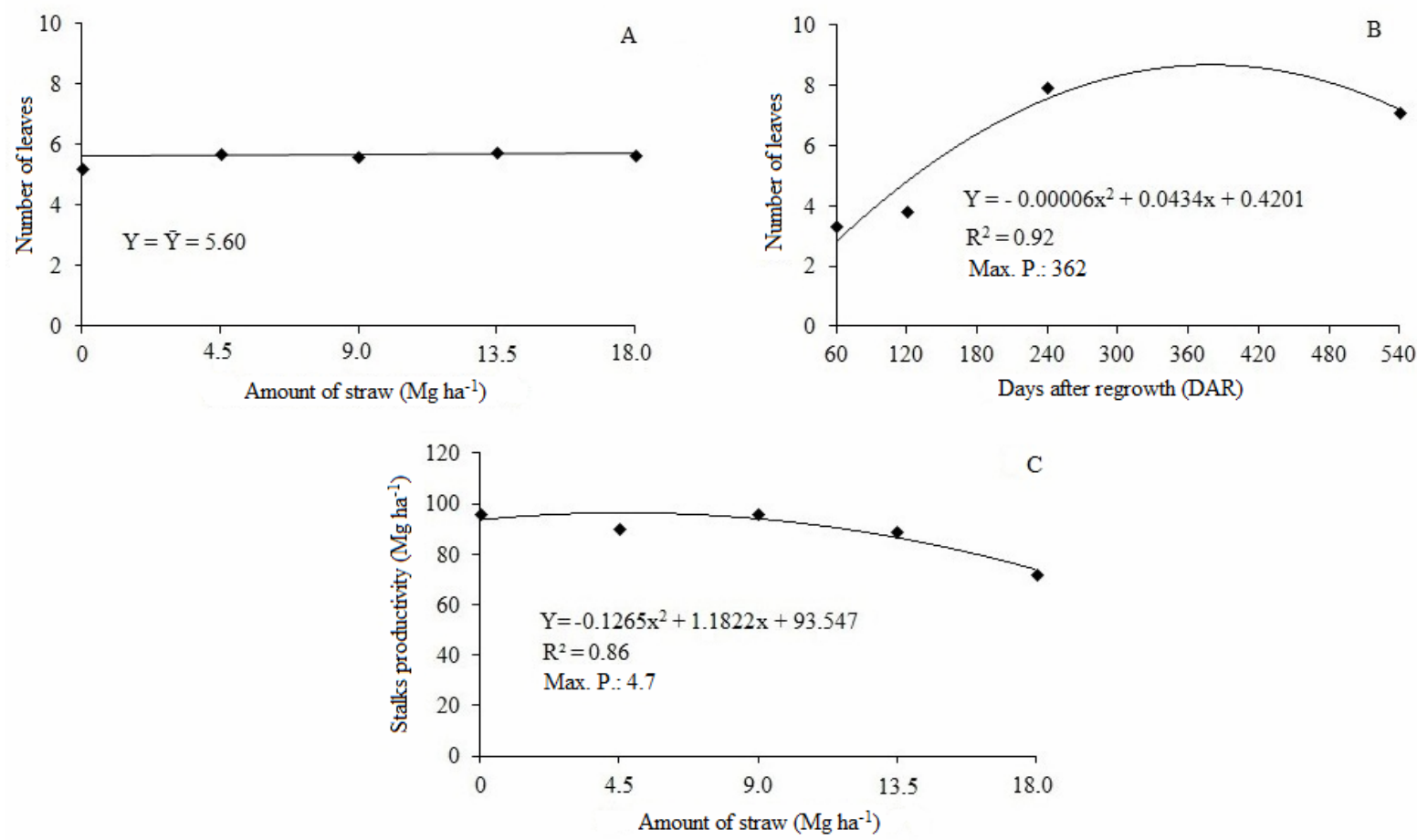

The quantification of the straw to be maintained on the soil surface lends sustainability to the sugarcane production system, and the removal of excess straw can be useful in the expansion of the potential of the sugar-ethanol sector, without increasing the area of cultivation. The biomass from the straw is a raw material with high potential for generating heat, producing cellulosic ethanol, and co-generating bioelectricity, which could contribute to the maximum energy re-use for the sector, in addition to environmental preservation and financial gains for the country. Thus, it is indispensable to continue studies similar to these in field conditions, with different cultivars and periods of crop installation, to obtain results that satisfy or increase the understanding of the dynamics of straw in the sugarcane crop system.

Therefore, we conclude that an increase in the amount of straw deposited on the soil surface reduces the number and diameter of the stalks during the early establishment of the crop, and the number of leaves for first-cycle cane, without influencing 
the second cycle. Maximum stalk productivity is obtained with the maintenance of $9.5 \mathrm{Mg} \mathrm{ha}^{-1}$ of straw for the first cycle and $4.7 \mathrm{Mg} \mathrm{ha}^{-1}$ of straw for the second cycle.

\section{Acknowledgements}

The authors are grateful to the Bandeirantes Sugar and Alcohol Plant (USIBAN) for their assistance during the development of the study, as well as the Coordination for the Improvement of Higher Education Personnel (Coordenação de Aperfeiçoamento de Pessoal de Nível Superior (CAPES)) for financial support.

\section{References}

AlvareZ, I. A.; CASTRO, P. R. C. Crescimento da parte aérea de cana crua e queimada. Scientia Agricola, Piracicaba, v. 56, n. 4, p. 1069-1079, 1999.

AQUINO, G. S.; MEDINA, C. C. Crescimento e produtividade de cana-de-açúcar sob doses de palhada. In: SEMINÁRIO DE GESTÃO AMBIENTAL NA AGROPECUÁRIA, 3., 2012, Bento Gonçalves. Anais... Bento Gonçalves: Fundação Proamb, 2012. Disponível em: $\quad<$ http://www.proamb.com.br/downloads/pnd5xr. pdf $>$. Acesso em: 10 jul. 2015.

AZANIA, C. A. M.; AZANIA, A. A. P. M.; FURTADO, D. E. Biologia e manejo de plantas daninhas em cana-deaçúcar. In: SEGATO, S. V.; PINTO, A. S.; JENDIROBA, E.; NÓBREGA, J. C. M. (Ed.). Atualização em produção de cana-de-açúcar. Piracicaba: CP 2, 2006. p. 174-190.

BRAUNBECK, O. A.; MAGALHÃES, P. S. G. Avaliação tecnológica da mecanização da cana-de-açúcar. In: CORTEZ, L. A. B. (Ed.). Bioetanol de cana-de-açúcar. São Paulo: Blucher, 2010. p. 451-475.

CASAGRANDE, A. A. Tópicos de morfologia e fisiologia da cana-de-açúcar. Jaboticabal: FUNEP, 1991. $157 \mathrm{p}$.

CEDDIA, M. B.; ANJOS, L. H. C.; LIMA, E.; RAVELLI NETO, A.; SILVA, L.A. Sistemas de colheita da canade-açúcar e alterações nas propriedades físicas de um solo Podzólico Amarelo no Estado do Espírito Santo. Pesquisa Agropecuária Brasileira, Brasília, v. 34, n. 8, p. 1467-1473, 1999.

CHRISTOFFOLETI, P. J.; CARVALHO, S. J. P.; LÓPEZ-OVEJERO, R. F.; NICOLAI, M.; HIDALGO,
E.; SILVA, J. E. Conservation of natural resources in Brazilian agriculture: implications on weed biology and management. Crop Protection, Guildford, v. 26, n. 3, p. 383-389, 2007.

COMPANHIA NACIONAL DE ABASTECIMENTO CONAB. Acompanhamento da safra Brasileira: cana-deaçúcar. Primeiro levantamento. Brasília: CONAB, 2015. $28 \mathrm{p}$.

DAWSON, L.; BOOPATHY, R. Use of post-harvest sugarcane residue for ethanol production. Bioresource Technology, Miramar, v. 98, n. 9, p. 1695-1699, 2007.

EMPRESA BRASILEIRA DE PESQUISA AGROPECUÁRIA - EMBRAPA. Sistema Brasileiro de Classificação de Solos. Rio de Janeiro: Embrapa, 2006. $306 \mathrm{p}$.

FERREIRA, D. F. SISVAR: sistema de análise de variância. Versão 5.3. Lavras: UFLA, 2010.

FREITAS, P. S. L.; MANTOVANI, E. C.; SEDIYAMA, G. C.; COSTA, L. C. Efeito da cobertura de resíduo da cultura do milho na evaporação da água do solo. Revista Brasileira de Engenharia Agrícola e Ambiental, Campina Grande, v. 8, n. 1, p. 85-91, 2004.

GAVA, G. J. C.; TRIVELIN, P. C. O.; OLIVEIRA, M. W.; PENATTI, C. P. Crescimento e acúmulo de nitrogênio em cana-de-açúcar cultivada em solo coberto com palhada. Pesquisa Agropecuária Brasileira, Brasília, v. 36, n. 11, p. 1347-1354, 2001.

INSTITUTO AGRONÔMICO DO PARANÁ - IAPAR. Sistema de monitoramento agroclimático do Paraná. Londrina: Iapar, 2015. Disponível em: <http://www.iapar. br/arquivos/Image/monitoramento/Medias_Historicas/ Bandeirantes.htm $>$. Acesso em: 22 jun. $201 \overline{5}$.

LUCA, E. F.; FELLER, C.; CERRI, C. C.; BARTHÈS, B.; CHAPLOT, V.; CAMPOS, D. C.; MANECHINI, C. Avaliação de atributos físicos e estoques de carbono e nitrogênio em solos com queima e sem queima de canavial. Revista Brasileira de Ciências do Solo, Viçosa, MG, v. 32, n. 2, p. 789-800, 2008.

MACEDO, N. M.; BOTELHO, P. S. M.; CAMPOS, M. B. S. Controle químico de cigarrinha-da-raiz em canade-açúcar e impacto sobre a população de artrópodes. Revista Stab, Piracicaba, v. 21, n. 4, p. 30-33, 2003.

MENDOZA, H. N. S.; LIMA, E.; ANJOS, L. H. C.; SILVA, L. A.; CEDDIA, M. B.; ANTUNES, M. V. M. Propriedades químicas e biológicas de solo de tabuleiro cultivado com cana-de-açúcar com e sem queima da palhada. Revista Brasileira de Ciência do Solo, Viçosa, MG, v. 24, n. 1, p. 201-207, 2000. 
MONQUERO, P. A.; AMARAL, L. R.; BINHA, D. P.; SILVA, P. V.; SILVA, A. C.; MARTINS, F. R. A. Mapas de infestação de plantas daninhas em diferentes Sistemas de colheita da cana-de-açúcar. Revista Planta Daninha, Viçosa, MG, v. 26, n. 1, p. 47-55, 2008.

OLIVEIRA, A. P. P.; LIMA, L.; ANJOS, L. H. C.; ZONTA, E.; PEREIRA, M. G. Sistemas de colheita da cana-de-açúcar: conhecimento atual sobre modificações em atributos de solos de tabuleiro. Revista Brasileira de Engenharia Agrícola e Ambiental, Campina Grande, v. 18, n. 9, p. 939-947, 2014.

OLIVEIRA, J. C. M.; TIMM, L. C.; TOMNAGA, T. T.; CÁSSARO, F. A. M.; REICHARDT, K.; BACCHI, O. O. S.; DOURADO NETO, D.; CÂMARA, G. M. S. Soil temperature in a sugar-cane crop as a function of the management system. Plant and Soil, The Hague, v. 230, n. 1, p. 61-66, 2001.

OLIVEIRA, R. A.; DAROS, E.; ZAMBON, J. L. C.; WEBER, H.; IDO, O. T.; BESPALHOK-FILHO, J. C.; ZUFFELLATO-RIBAS, K. C.; SILVA, D. K. T. Área foliar em três cultivares de cana-de-açúcar e sua correlação com a produção de biomassa. Pesquisa Agropecuária Tropical, Goiânia, v. 37, n. 2, p. 71-76, 2007.

PANOSSO, A. R.; MARQUES JUNIOR, J.; MILORI, D. M. B. P.; FERRAUDO, A. S.; BARBIERI, D. M.; PEREIRA, G. T.; LA SCALA JUNIOR, N. Soil $\mathrm{CO}_{2}$ emission and its relation to soil properties in sugarcane areas under Slash-and-burn and Green harvest. Soil and Tillage Research, v. 111, n. 2, p. 190-196, 2011.

PAREDES JUNIOR, F. P.; PORTILHO, I. I. R.; MERCANTE, F. M. Atributos microbiológicos de um latossolo sob cultivo de cana-de-açúcar com e sem queima da palhada. Semina: Ciências Agrárias, Londrina, v. 36, n. 1, p. 151-164, 2015.

PITELI, R. A.; DURIGAN, J. C. Ecologia e das plantas daninhas no sistema de plantio direto. In: ROSSELLO, R. D. (Ed.). Siembra directa em Cono Sur. Montevideo: UY. PROCISUR, 2001. p. 203-210.

RAIJ, B. V.; QUAGGIO, A. J. Métodos de análise de solo para fins de fertilidade. Campinas: Instituto Agronômico, 1983. $31 \mathrm{p}$.
RAMESH, P. Effect of different levels of drought during the formative phase on growth parameters and its relationship with dry matter accumulation in sugarcane. Journal of Agronomy and Crop Science, Madison, v. 185, n. 2, p. 83-89, 2000.

RICE, E. L. Allelopathy. New York: Academic Press, 1984. $422 \mathrm{p}$.

REDE INTERUNIVERSITÁRIA PARA O DESENVOLVIMENTO DO SETOR SUCROALCOOLEIRO - RIDESA. Catálogo nacional de variedades RB de cana-de-acúcar. Curitiba: RIDESA, 2010. $136 \mathrm{p}$.

SOUZA, Z. M.; PRADO, R. M.; PAIXÃO, A. C. S.; CESARIN, L. G. Sistemas de colheita e manejo da palhada de cana-de-açúcar. Pesquisa Agropecuária Brasileira, Brasília, v. 40, n. 3, p. 271-278, 2005.

TAVARES, O. C. H.; LIMA, E.; ZONTA, E. Crescimento e produtividade da cana planta cultivada em diferentes sistemas de preparo do solo e de colheita. Acta Scientiarum, Agronomy, Maringá, v. 32, n. 1, p. 61-68, 2010.

TIMM, L. C.; OLIVEIRA, J. C. M.; TOMINAGA, T. T.; CASSARO, F. A. M.; REICHARDT, K.; BACCHI, O. O. S. Water balance of a sugar cane crop: quantitative and qualitative aspects. Revista Brasileira de Engenharia Agrícola e Ambiental, Campina Grande, v. 6, n. 1, p. 5762, 2002.

VALIM, W. C.; PANACHUKI, E.; PAVEI, D. S.; SOBRINHO, T. A.; ALMEIDA, W. S. Effect of sugracane wast in the controlo of interrill erosin. Semina: Ciências Agrárias, Londrina, v. 37, n. 3, p. 1155-1164, 2016.

VASCONCELOS, A. C. M. Desenvolvimento do sistema radicular e da parte aérea de socas de cana-de-açúcar sob dois sistemas de colheita: crua mecanizada e queimada manual. 2002. Tese (Doutorado em Agronomia) - Faculdade de Ciências agrárias e Veterinárias, Universidade Estadual Paulista Júlio de Mesquita Filho, Jaboticabal.

VELINI, E. D.; NEGRISOLI, E. Contraste de plantas daninhas em cana crua. In: CONGRESSO BRASILEIRO DE CIÊNCIA DAS PLANTAS DANINHAS, 22., 2001, Foz do Iguaçu. Palestra... Foz do Iguaçu: Congresso Brasileiro de Ciência das Plantas Daninhas, 2001. p. 148164. 